\title{
23. CARBON ISOTOPE COMPOSITIONS OF ORGANIC MATTER FROM THE CHILE CONTINENTAL MARGIN ${ }^{1}$
}

\author{
Amane Waseda, ${ }^{2}$ Borys M. Didyk, ${ }^{3}$ and Yoshiteru Kajiwara ${ }^{2}$
}

\begin{abstract}
Stable carbon isotope compositions as well as organic carbon contents and pyrolysis results of cored material are reported for the Pliocene to Pleistocene sediments from the Ocean Drilling Program (ODP) Sites $859,860,861$, and 863 . The $\delta^{13} \mathrm{C}$ values of kerogen show large variation with no downhole trend, ranging between $-34.2 \%$ and $-22.6 \%$ with average values around $-25 \%$, whereas the organic carbon contents in most sediment samples are consistently low $(<0.5 \%)$ except for enrichment in the surface layer at Sites 859,860 , and 861 . The $\delta^{13} \mathrm{C}$ values of kerogen indicate the kerogen in sediments of the Chile Margin has a predominantly terrestrial origin, and the fine-grained turbidite material is associated with terrestrial organic matter. The average $\delta^{13} \mathrm{C}$ values become lighter with increasing distance from land among three sites drilled along an east-west transect, suggesting fine turbidites with terrestrial organic matter are transported further offshore in this trench-slope setting.
\end{abstract}

\section{INTRODUCTION}

During Ocean Drilling Program Leg 141 in the vicinity of the Chile Triple Junction, the Pliocene to Pleistocene sedimentary sequences were recovered at four sites on the Chile continental slope (Fig. 1). This paper reports the results of stable carbon isotope measurements, organic carbon contents, and pyrolysis results for samples collected at Sites 859, 860, 861, and 863 from Leg 141 .

The carbon isotope compositions of organic matter in sediments are used to determine the variation of relative proportions of terrigenous and marine organic carbon inputs (Sackett, 1989). In many marine environments, relative contributions of terrigenous and marine inputs have been documented through the use of stable carbon isotopes and paleoclimate has been inferred. The carbon isotope compositions of the kerogens have indicated the sediments of the Nankai accretionary prism, Japan contain a higher portion of terrestrial organic matter (Berner and Koch, 1993). In the Gulf of Mexico, downcore variations have been correlated with glacial and interglacial episodes which are related to sea-level lowering and the changing influence of the Mississippi River (Parker et al., 1972; Newman et al., 1973). The influence of glacial episodes on marine sequences has been also inferred from the isotopic compositions of organic matter in sediments of the Oman Margin (Muzka et al., 1991), the Labrador Sea, and Baffin Bay (Macko, 1989).

The use of $\delta^{13} \mathrm{C}$ values as a parameter of relative proportions of terrigenous and marine organic carbon inputs are based on the premise that the $\delta^{13} \mathrm{C}$ values of organic material in sediments are reflective of the isotope composition of the source biota and do not change through diagenesis. The factors of diagenesis that may be of importance in affecting the carbon isotope composition include: (1) isotope effects during bacterial degradation of organic matter; (2) preferential elimination of compound groups and preferential preservation of others which differ significantly in $\delta^{13} \mathrm{C}$ from the average plant material; and (3) decarboxylation reactions, which would remove ${ }^{13} \mathrm{C}$ enriched groups from the organic material leading to ${ }^{13} \mathrm{C}$ depletion in the residual (Deines, 1980). However, consistent diagenetic trends in sediments are difficult to document (Deines, 1980; Galimov, 1980;

\footnotetext{
'Lewis, S.D., Behrmann, J.H., Musgrave, R.J., and Cande, S.C. (Eds.), 1995. Proc, ODP, Sci. Results, 141: College Station, TX (Ocean Drilling Program).

2 JAPEX Research Center, 1-2-1 Hamada, Mihama-ku, Chiba 261, Japan.

${ }^{3}$ Empresa Nacional del Petróleo, Refinería de Petróleos Concón S.A., Casilla 28-D. Viña del Mal, Chile.
}

Sackett, 1989). Thus these diagenetic factors above probably can account for only minor changes of 1 or $2 \%$ in the $\delta^{13} \mathrm{C}$ of organic carbon, but do not produce a significant carbon isotope shift in Miocene to Holocene sediments (Arthur et al., 1985; Dean et al., 1986).

The carbon isotope composition of organic matter in sediments has been also used as a paleotemperature tool for studying deep-sea sediments, which is based on temperature-dependent fractionation of carbon isotopes by marine phytoplankton (Sackett, 1989). The basic premise in the use of $\delta^{13} \mathrm{C}$ values of organic matter as a paleotemperature parameter is that all of the organic matter in the sediments was synthesized by algae growing in an open marine environment. The sediments from Leg 141 were predominantly deposited in a trenchslope environment and consist of continent-derived debris or turbidity flow deposits. This tool therefore can not be applied to the sediment in this study, and the variations in isotope signature possibly represent the variation of relative proportions of terrigenous and marine organic carbon inputs. This paper gives an overview of the origin of organic matter in relation to the trench-slope sedimentary environment near the Chile Triple Junction.

\section{GEOLOGIC SETTING}

At the Chile Triple Junction (Fig. 1) an active spreading ridge and adjacent young oceanic crust are being subducted beneath the continent of South America. During ODPLeg 141, Pliocene to Pleistocene sedimentary sequences were recovered at four sites. Three sites $(859$, 860 , and 861) were drilled along an east-west dip transect about 35 $\mathrm{km}$ north of the Chile Triple Junction at water depths ranging from 1652 to $2741 \mathrm{~m}$. Site 863 ( $2564 \mathrm{~m}$ water depth) was drilled at the base of a trench-slope basin directly above the subducted spreading axis as a strike transect with Site 859 .

\section{METHODS}

Wet sediment samples were dried for 16 hours at $60^{\circ} \mathrm{C}$ and then crushed and acidified with $6 \mathrm{~N} \mathrm{HCl}$ to remove carbonate. The carbonate-free residue was then washed, dried, and sonically extracted with a benzene-methanol mixture (7:3). A portion of dried material was then weighed and combusted in a quartz glass tube for $2 \mathrm{hr}$ at $900^{\circ} \mathrm{C}$ in presence of purified cupric oxide wire and silver granule. The $\mathrm{CO}_{2}$ gases obtained were cryogenically isolated from other combustion products and analyzed on a VG Isotech Sira Series II mass spectrometer. The carbon isotope ratios are reported in the usual $\delta$-notation relative to the PDB (Pee Dee Belemnite) standard: 


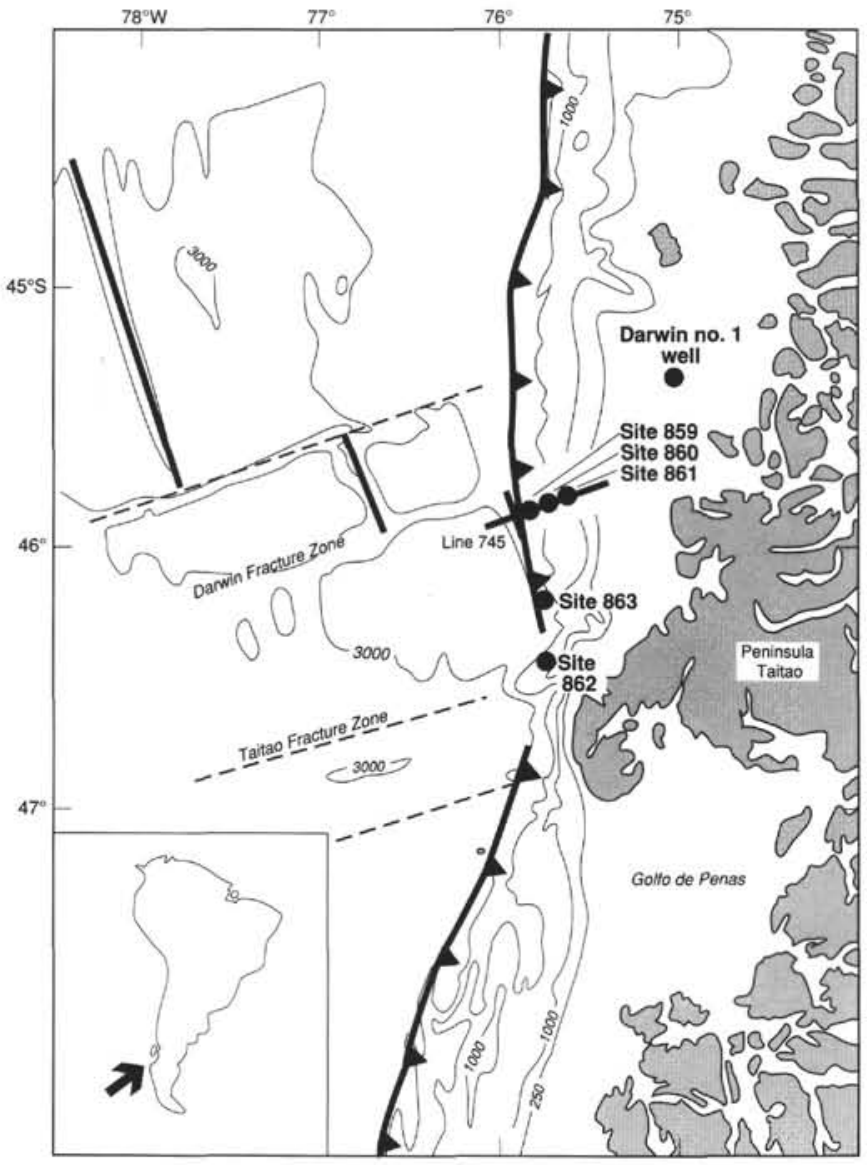

Figure 1. Tectonic sketch map of the Chile Triple Junction and its surroundings showing location of Sites $859,860,861$, and 863 . Solid bold lines indicate spreading segments of the Chile Ridge, separating Nazca Plate (north) and Antarctic Plate (south), barbed line is the frontal thrust of the South American forearc.

$$
\delta^{13} \mathrm{C}(\%)=\left\{\left[\left({ }^{13} \mathrm{C} /{ }^{12} \mathrm{C}\right)_{\text {sample }} /\left({ }^{13} \mathrm{C} /{ }^{12} \mathrm{C}\right)_{\text {standard }}\right]-1\right\} \times 1000 .
$$

The reproducibility of $\delta^{13} \mathrm{C}(\%)$ in combustion and measurement is within $\pm 0.2 \%$.

The total organic carbon (TOC) contents of carbonate-free residue were determined using Yanaco MT-3 CHN Corder. The TOC of the whole rock were calculated by correcting for carbonate removal.

Rock-Eval pyrolyses of whole rock samples was carried out using a Rock-Eval II as described by Espitalié et al. (1977). Programmed pyrolysis of samples from $300^{\circ} \mathrm{C}$ to $550^{\circ} \mathrm{C}$ gives the amount of preformed hydrocarbons $\left(\mathrm{S}_{1}\right)$, the amount of hydrocarbons released during heating $\left(\mathrm{S}_{2}\right)$, and the amount of $\mathrm{CO}_{2}$ released during pyrolysis to $390^{\circ} \mathrm{C}\left(\mathrm{S}_{3}\right)$. These values provide the basis for calculation of the hydrogen index $(\mathrm{HI})$, where $\mathrm{HI}=100 \times \mathrm{S}_{2} / \mathrm{TOC}$, the oxygen index (OI), where $\mathrm{OI}=100 \times \mathrm{S}_{3} / \mathrm{TOC}$, the production index $(\mathrm{PI})$, where PI $=\mathrm{S}_{1} /\left[\mathrm{S}_{1}+\mathrm{S}_{2}\right]$. The temperature of maximum hydrocarbon release during pyrolysis $\left(\mathrm{T}_{\max }\right)$ is also obtained and can be interpreted as a measure of organic matter thermal maturity.

\section{RESULTS AND DISCUSSION}

The total organic carbon (TOC) contents of most samples are characterized by predominant low values, ranging from $0.2 \%$ to $0.5 \%$ and show no trend related to depth (Table 1). These values are typical for modern open-marine environments (McIver, 1975) and are similar to the sediments of Site 808, Nankai accretionary prism (Berner and Koch, 1993). On the other hand, in the same trench-slope system, organic carbon contents are much higher in upwelling area off Peru (up to 9\%; ten Haven et al., 1990). During Leg 108 in the northwest African continental margin, upwelling Site 658 displays high organic contents of $0.5 \%-4 \%$, whereas nonupwelling Sites 657 and 659 are characterized by low organic carbon values of less than $0.5 \%$ (Stein et al., 1989). These comparisons with results obtained from the other areas suggest the low organic carbon contents in the Chile Margin is mainly attributed to the low productivity of organic matter in this area. The depth profiles of TOC from Sites $859,860,861$, and 863 are shown in Figure 2. The shipboard data of TOC values are also plotted in Figure 2; data were determined using a Rock-Eval II with a TOC module at Sites 859,860 , and 861 and calculated by subtraction of the inorganic carbon content determined using a coulometer from the total carbon content determined using a CNS analyzer at Site 863. These TOC values determined through three different analytical methods are well comparable. The surface layer ( $<1$ mbsf [meters below seafloor]) show relatively higher TOC values $(>1.0 \%)$ at Sites 859,860 , and 861 , whereas no surface enrichment is observed at Site 863 . This surface enrichment at Site 859,860 , and 861 suggests that intensive bacterial degradation of organic matter occurs in near surface sediments at these sites. This is supported by the observation that high concentrations of bacterial methane exist at Site 859,860 , and 861 , whereas methane is not abundant at Site 863 (Waseda and Didyk, this volume).

Rock-Eval pyrolysis was only carried out for the samples which contain more than $0.3 \%$ TOC, since rocks containing low TOC are most likely to be strongly affected by adsorption of pyrolysate by the mineral matrix, resulting in reduced $\mathrm{S}_{2}$ and $\mathrm{HI}$ and increased $\mathrm{T}_{\max }$ and OI (Peters, 1986). The $S_{2}$ values of many samples are too low $(<0.2$ $\mathrm{mg} / \mathrm{g}$ ) to derive reliable interpretations, or $\mathrm{S}_{2}$ peaks in the pyrograms are broad or multiple. Since the $T_{\max }$ values of those samples do not represent true maturity of sedimentary strata, we have eliminated those data (Table 1). In spite of such data elimination, extensive scatter of the Rock-Eval $\mathrm{T}_{\max }$ values are observed, and no downhole maturity trend exists (Fig. 3). Most of the data exceeds $430^{\circ} \mathrm{C}$ equivalent to the threshold level for oil generation. However, actual level of thermal maturity should be low since the shallow depth of burial of the sediments and low bottom hole temperature. Maximum temperature at the bottom of the borehole measured by wireline during Leg 141 is $65^{\circ} \mathrm{C}$ at Site 863 (Behrmann, Lewis, Musgrave, et al., 1992). As mentioned above, the pyrograms of the samples occasionally contain multiple $\mathrm{S}_{2}$ peaks, which suggest multiple inputs that include recycled components. Other samples have pyrograms in which the $\mathrm{S}_{2}$ peaks are broad, partially resolved, and sloping humps. This pattern suggests that the clay-induced adsorption of the pyrolysates also contributes to the erroneously high $\mathrm{T}_{\max }$ values for some of the sediment samples.

The HI-OI diagram (Fig. 4) indicates the type of organic matter is Type III, terrestrial. This is consistent with the fact that the sediments have a turbidite and debris flow origin. However, taking into account the clay-induced adsorption effect, true $\mathrm{HI}$ values of organic matter maybe slightly higher. Therefore the sediments probably contain considerable amount of marine derived organic matter.

The carbon isotope compositions of kerogen range between -34.2 and $-22.6 \%$ with average values around $-25 \%$ (Table 1, Fig. 5). In recent sedimentary environments, the relative contributions of terrigenous and marine inputs have been estimated from stable carbon isotope compositions. Terrestrial plants are enriched in ${ }^{12} \mathrm{C}$ relative to marine plants. Tertiary kerogens of terrestrial origin have a carbon isotope range from $-24 \%$ to $-29 \%$ and modern land plants of the C-3 photosynthetic cycle range from $-24 \%$ to $-32 \%$, whereas marine plankton varies between $-18 \%$ and $-22 \%$ (Schoell, 1984, and literature cited therein). The carbon isotope values suggest that the kerogen in sediments of the Chile Margin has a predominantly terrestrial origin. This result is consistent with the result obtained from the 
Table 1. TOC, Rock-Eval, and kerogen carbon isotope data of Leg 141 sediments.

\begin{tabular}{|c|c|c|c|c|c|c|c|c|c|c|c|}
\hline $\begin{array}{l}\text { Core, section. } \\
\text { interval }(\mathrm{cm})\end{array}$ & $\begin{array}{l}\text { Depth } \\
\text { (mbsf) }\end{array}$ & $\begin{array}{l}\text { TOC } \\
(\%)\end{array}$ & 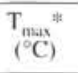 & $\begin{array}{c}\mathrm{S}_{1} \\
(\mathrm{mg} / \mathrm{g})\end{array}$ & $\frac{\mathrm{S}_{2}}{(\mathrm{mg} / \mathrm{g})}$ & $\underset{(\mathrm{mg} / \mathrm{g})}{\mathrm{S}_{3}}$ & $\mathrm{HI}$ & OI & $\mathrm{PI}$ & $\mathrm{S}_{2} / \mathrm{S}_{3}$ & $\begin{array}{l}\delta^{13} \mathrm{C} \\
(\%)\end{array}$ \\
\hline \multicolumn{12}{|l|}{$141-859 \mathrm{~A}-$} \\
\hline $1 \mathrm{H}-1.5-7$ & 0.05 & 0.86 & 440 & 0.60 & 1.47 & 1.93 & 171 & 224 & 0.18 & 0.76 & -22.9 \\
\hline $2 \mathrm{H}-1.148-150$ & 2.68 & 0.39 & 4.34 & 0.2 .3 & 0.45 & 0.96 & 115 & 246 & 0.16 & 0.47 & -28.2 \\
\hline $4 \mathrm{H}-4,41-4,3$ & 21.61 & 0.46 & 445 & 0.06 & 0.55 & 0.88 & 120 & 191 & 0.04 & 0.63 & -28.0 \\
\hline $6 \times-2,25-27$ & 36.45 & 0.15 & & & & & & & & & -24.9 \\
\hline $13 X-1.9-11$ & 78.09 & 0.30 & L & 0.02 & 0.11 & 0.53 & 37 & 177 & 0.03 & 0.21 & -29.5 \\
\hline \multicolumn{12}{|l|}{$141-8.59 \mathrm{~B}-$} \\
\hline |R-2.51-53 & 54.01 & 0.31 & L & 0.03 & 0.10 & 1.12 & 32 & 361 & 0.02 & 0.09 & -25.2 \\
\hline $4 R-1.50-52$ & 140.50 & 0.23 & & & & & & & & & -32.8 \\
\hline IIR-I. 54-56 & 206.94 & 0.36 & L & 0.03 & 0.17 & 0.23 & 47 & 64 & 0.08 & 0.74 & -29.1 \\
\hline $14 \mathrm{R}-3,40-43$ & 238.70 & 0.14 & & & & & & & & & -25.4 \\
\hline $19 R-3.62-64$ & 287.12 & 0.24 & & & & & & & & & -32.8 \\
\hline $21 R-3,36-39$ & 306.16 & 0.13 & & & & & & & & & -27.1 \\
\hline $22 \mathrm{R}-1.106-108$ & 313.26 & 0.25 & & & & & & & & & -24.9 \\
\hline $25 \mathrm{R}-4,110-113$ & 346.80 & 0.35 & 441 & 0.17 & 0.39 & 0.09 & 111 & 26 & 0.35 & 4.33 & -27.9 \\
\hline $30 \mathrm{R}-4,80-83$ & 394.50 & 0.31 & $\mathrm{M}$ & 0.17 & 0.63 & 0.12 & 203 & 39 & 0.23 & 5.25 & -28.7 \\
\hline $33 R-1.62-65$ & 418.92 & 0.23 & & & & & & & & & -24.2 \\
\hline $38 R-1.118-121$ & 467.58 & 0.29 & & & & & & & & & -28.6 \\
\hline \multicolumn{12}{|l|}{$141-860 \mathrm{~B}-$} \\
\hline $1 \mathrm{H}-1.13-15$ & 0.13 & 1.08 & 441 & 0.96 & 2.90 & 2.67 & 269 & 247 & 0.17 & 1.09 & -23.3 \\
\hline $4 \mathrm{H}-4,86-88$ & 25.76 & 0.30 & B & 0.24 & 0.48 & 0.65 & 160 & 217 & 0.21 & 0.74 & -23.9 \\
\hline $7 \mathrm{H}-3.126-129$ & 53,16 & 0.41 & B & 0.34 & 0.78 & 0.93 & 190 & 227 & 0.20 & 0.84 & -27.5 \\
\hline $16 \mathrm{X}-2,87-90$ & 119.17 & 0.72 & B & 0.67 & 1.27 & 1.02 & 176 & 142 & 0.29 & 1.25 & -25.1 \\
\hline $19 X-3,74-77$ & 140.84 & 0.59 & B & 0.32 & 0.75 & 1.34 & 127 & 227 & 0.15 & 0.56 & -28.4 \\
\hline $29 X-1.67-70$ & 233.47 & 0.32 & 435 & 0.06 & 0.49 & 1.20 & 153 & 375 & 0.04 & 0.41 & -34.2 \\
\hline $31 X-3,48-50$ & 255.38 & 0.82 & 426 & 0.14 & 1.48 & 0.73 & 180 & 89 & 0.06 & 2.03 & -23.0 \\
\hline $34 X-2.75-78$ & 283.05 & 0.38 & B & 0.06 & 0.54 & 0.34 & 142 & 89 & 0.07 & 1.59 & -23.2 \\
\hline $39 X-1.60-63$ & 329.30 & 0.36 & 438 & 0.06 & 0.45 & 0.25 & 125 & 69 & 0.09 & 1.80 & -24.1 \\
\hline $41 \times-4.60-62$ & 353.10 & 0.37 & 428 & 0.07 & 0.49 & 0.38 & 132 & 103 & 0.08 & 1.29 & -24.1 \\
\hline $46 X-1.81-84$ & 387.41 & 0.32 & B & 0.05 & 0.57 & 0.32 & 178 & 100 & 0.06 & 1.78 & -27.7 \\
\hline $47 X-C C .42-44$ & 396.72 & 0.30 & B & 0.08 & 0.62 & 0.30 & 207 & 100 & 0.09 & 2.07 & -23.1 \\
\hline $62 X-2.59-62$ & 532.99 & 0.39 & 431 & 0.08 & 0.48 & 0.48 & 123 & 123 & 0.08 & 1.00 & -22.8 \\
\hline $64 X-3,35-37$ & 552.55 & 0.18 & & & & & & & & & -24.3 \\
\hline \multicolumn{12}{|l|}{$141-861 \mathrm{~A}-$} \\
\hline IH-I.94-97 & 0.94 & 0.44 & M & 0.23 & 0.68 & 0.37 & 155 & 84 & 0.22 & 1.84 & -22.8 \\
\hline \multicolumn{12}{|l|}{$141-861 \mathrm{C}-$} \\
\hline $\mathrm{IH}-2.82-84$ & 2.32 & 0.56 & M & 0.35 & 1.41 & 0.87 & 252 & 155 & 0.15 & 1.62 & -22.6 \\
\hline $4 \mathrm{H}-1.115-120$ & 23.15 & 0.36 & B & 0.24 & 0.46 & 0.38 & 128 & 106 & 0.29 & 1.21 & -26.6 \\
\hline $7 \mathrm{H}-3.111-113$ & 54.61 & 0.19 & & & & & & & & & -25.9 \\
\hline $\mathrm{IOH}-3,39-42$ & 74.39 & 0.26 & & & & & & & & & -27.1 \\
\hline $12 X-2,43-46$ & 92.03 & 0.30 & B & 0.10 & 0.50 & 0.44 & 167 & 147 & 0.11 & 1.14 & -2.3 .7 \\
\hline $16 X-2.35-38$ & 130.75 & 0.51 & M & 0.19 & 0.74 & 0.45 & 145 & 88 & 0.16 & 1.64 & -23.3 \\
\hline $18 \times-4,57-59$ & 153.57 & 0.30 & M & 0.06 & 0.41 & 0.30 & 137 & 100 & 0.08 & 1.37 & -23.9 \\
\hline $21 \times-1.36-39$ & 170.56 & 0.47 & M & 0.23 & 1.30 & 0.64 & 277 & 1,36 & 0.12 & 2.03 & -25.1 \\
\hline $22 X-5,31-34$ & 186.21 & 0.36 & B & 0.12 & 0.55 & 0.62 & 153 & 172 & 0.10 & 0.89 & -23.5 \\
\hline $25 X-3,51-54$ & 212.41 & 0.35 & 429 & 0.09 & 0.28 & 0.46 & 80 & 131 & 0.12 & 0.61 & -24.3 \\
\hline $29 \times-1.107-109$ & 238.77 & 0.18 & & & & & & & & & -25.1 \\
\hline $31 \times-2.83-86$ & 250.63 & 0.44 & 419 & 0.09 & 0.54 & 0.46 & 123 & 105 & 0.09 & 1.17 & -23.6 \\
\hline $34 X-5,35-38$ & 280.12 & 0.22 & & & & & & & & & -25.3 \\
\hline $37 X-2,50-52$ & 306.90 & 0.43 & B & 0.30 & 0.71 & 0.49 & 165 & 114 & 0.25 & 1.45 & -23.5 \\
\hline $41 X-3,45-48$ & 346.85 & 0.34 & B & 0.10 & 0.52 & 0.35 & 153 & 103 & 0.11 & 1.49 & -22.9 \\
\hline \multicolumn{12}{|l|}{ 141-861D- } \\
\hline IR-2, 10-13 & 343,90 & 0.38 & 448 & 0.06 & 0.54 & 0.39 & 142 & 103 & 0.06 & $\begin{array}{l}1.38 \\
0.78\end{array}$ & -24.3 \\
\hline $6 \mathrm{R}-3,23-25$ & 392.13 & 0.31 & B & 0.07 & 0.45 & 0.58 & 145 & 187 & 0.07 & 0.78 & -23.2 \\
\hline $7 R-2,38-41$ & 401.98 & 0.42 & M & 0.07 & 0.55 & 0.60 & 131 & 143 & 0.06 & 0.92 & -24.6 \\
\hline $13 R-3.29-32$ & 460.82 & 0.38 & M & 0.11 & 0.61 & 0.45 & 161 & 118 & 0.10 & 1.36 & -24.3 \\
\hline I5R-2. $46-49$ & 477.76 & 0.36 & 4.38 & 0.06 & 0.59 & 0.50 & 164 & 139 & 0.06 & 1.18 & -23.8 \\
\hline \multicolumn{12}{|l|}{ 141-863A- } \\
\hline IH-4, 83-86 & 5.33 & 0.17 & & & & & & & & & -25.6 \\
\hline $5 \mathrm{H}-1,72-74$ & 37.82 & 0.22 & & & & & & & & & -25.0 \\
\hline $7 X-1.36-39$ & 56.46 & 0.33 & 446 & 0.08 & 0.43 & 0.67 & 130 & 203 & 0.07 & 0.64 & -25.4 \\
\hline $21 X-1,29-31$ & 191.59 & 0.23 & & & & & & & & & -26.1 \\
\hline $25 X-1,38-40$ & 230.18 & 0.39 & 445 & 0.06 & 0.55 & 0.43 & 141 & 110 & 0.06 & 1.28 & -23.4 \\
\hline 141-863B- & & & & & & & & & & & \\
\hline $4 X-3,82-84$ & 329.72 & 0.14 & & & & & & & & & -24.8 \\
\hline $7 \mathrm{~N}-2.11-15$ & 356.51 & 0.20 & & & & & & & & & -24.7 \\
\hline $10 R-1.0-2$ & 371.00 & 0.26 & & & & & & & & & -26.7 \\
\hline $17 R-5,124-126$ & 441.64 & 0.18 & & & & & & & & & -24.8 \\
\hline $26 \mathrm{R}-2,98-100$ & 522.93 & 0.19 & & & & & & & & & -24.2 \\
\hline $31 \mathrm{R}-2,34-36$ & 570.94 & 0.27 & & & & & & & & & -24.9 \\
\hline $49 R-4.100-102$ & 7.38 .70 & 0.23 & & & & & & & & & -23.8 \\
\hline
\end{tabular}

Notes: Blanks indicate not determined for low TOC $(<0.3 \%){ }^{*}$ indicates values were not determined for many samples for the following reasons: $\mathrm{L}=\mathrm{S}_{2}$ values are too low $(<0.2 \mathrm{mg} / \mathrm{g})$ to derive reliable interpretations; $\mathrm{B}=\mathrm{S}_{2}$ peaks are too broad; $\mathrm{M}=$ multiple $\mathrm{S}_{2}$ peaks. 


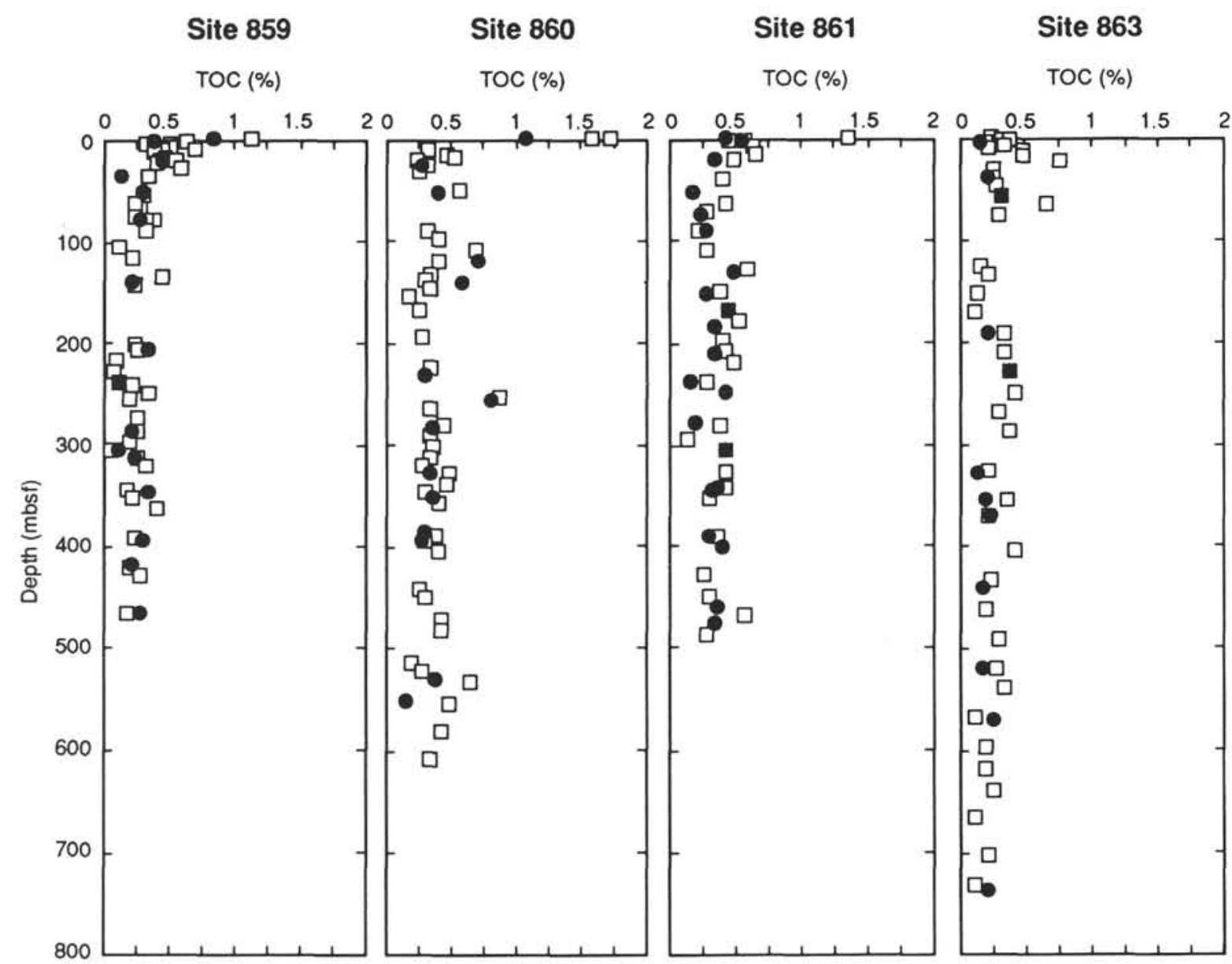

Figure 2. Total organic carbon (TOC) profile of sediment samples at Sites $859,860,861$, and 863 . Sample symbols: solid circles $=$ this study; squares $=$ shipboard analyses.

carbon isotope data of kerogen in sediments of Site 808, Nankai accretionary prism, Japan (Berner and Koch, 1993). In contrast, the organic matter in organic-rich sediments underlying active upwelling area off Peru has a predominantly marine planktonic and bacterial origin, with minor terrigenous contribution (ten Haven et al., 1990). The relationship between the carbon isotope compositions and $\mathrm{HI}$ values show slightly positive correlation (Fig. 6). HI values of marine organic matter are usually higher than terrestrial organic matter. The positive correlation is thus interpreted to indicate mixing of marine organic matter with heavier $\delta^{13} \mathrm{C}$ values and higher $\mathrm{HI}$, and terrestrial organic matter with lighter $\delta^{13} \mathrm{C}$ values and lower $\mathrm{HI}$.

The average carbon isotope values become lighter with increasing distance from land (from Site 861 through 859) among three sites drilled along an east-west transect (Fig. 5), and suggest an increasing terrigenous organic carbon flux with increasing distance from land. In normal shelf sediments, surficial sediments contain increasing amounts of the heavier isotope of carbon $\left({ }^{13} \mathrm{C}\right)$ with increasing distance from land and suggest a decreasing terrigenous carbon influence (Hedges and Parker, 1976). The reverse relationship between the relative contribution of terrigenous organic carbon inputs and the distance from land is observed in continental slope sediments in this study. The comparison of the sedimentological core description (Behrmann, Lewis, Musgrave, et al., 1992) and the $\delta^{13} \mathrm{C}$ values of kerogen revealed that samples taken from the section interpreted to be turbidites have lighter $\delta^{13}$ values and samples taken from the section interpreted to be pelagic fallouts have heavier $\delta^{13} \mathrm{C}$ values, indicating the fine-grained turbidite material is associated with terrestrial organic matter. Sediments in this region mainly consist of debris flow or turbidity flow deposits. At
Site 861 sediments predominantly consist of sands and conglomerates which represent more proximal facies of debris flow or turbidity flow, whereas more distal facies of turbidity flow are deposited at Sites 859 and 860 (Fig. 7; Shipboard Scientific Party, 1992). All samples for organic matter analyses were taken from the fine part of sediments. The proportions of fine particles in turbidite sequences increase with increasing distance from land. Therefore, the parts of fine sediments derived from muddy turbidites with terrigenous organic matter increase with increasing distance from land whereas the parts of fine sediments deposited by pelagic fallout containing more marine organic matter decrease with increasing distance from land. The $\delta^{13} \mathrm{C}$ values of kerogen at Site 859 and 860 show large fluctuations compared to Site 861 (Fig. 5). Fine sediments sampled at Site 861 may represent predominantly pelagic fallouts with heavier $\delta^{13} \mathrm{C}$ values. On the other hand at Sites 859 and 860 , some parts of muddy sections may represent turbidites with lighter $\delta^{13} \mathrm{C}$ values and some parts may represent pelagic fallouts.

Areal difference of marine organic productivity is another factor controlling the relative contributions of terrigenous and marine inputs to sediments. Since the production of marine organic matter is more active in coastal area than offshore area, the marine organic carbon flux decrease with increasing distance from land. Glacial environments also affect the transport of terrigenous material to sediments. In glacial periods, more terrigenous organic matter is transported to offshore due to sea-level lowering, and lateral transport of terrestrial debris is enhanced by ice rafting (Gearing et al., 1977). Therefore, the variation of the $\delta^{13} \mathrm{C}$ values of kerogen may partially reflect glacial and interglacial episodes. 


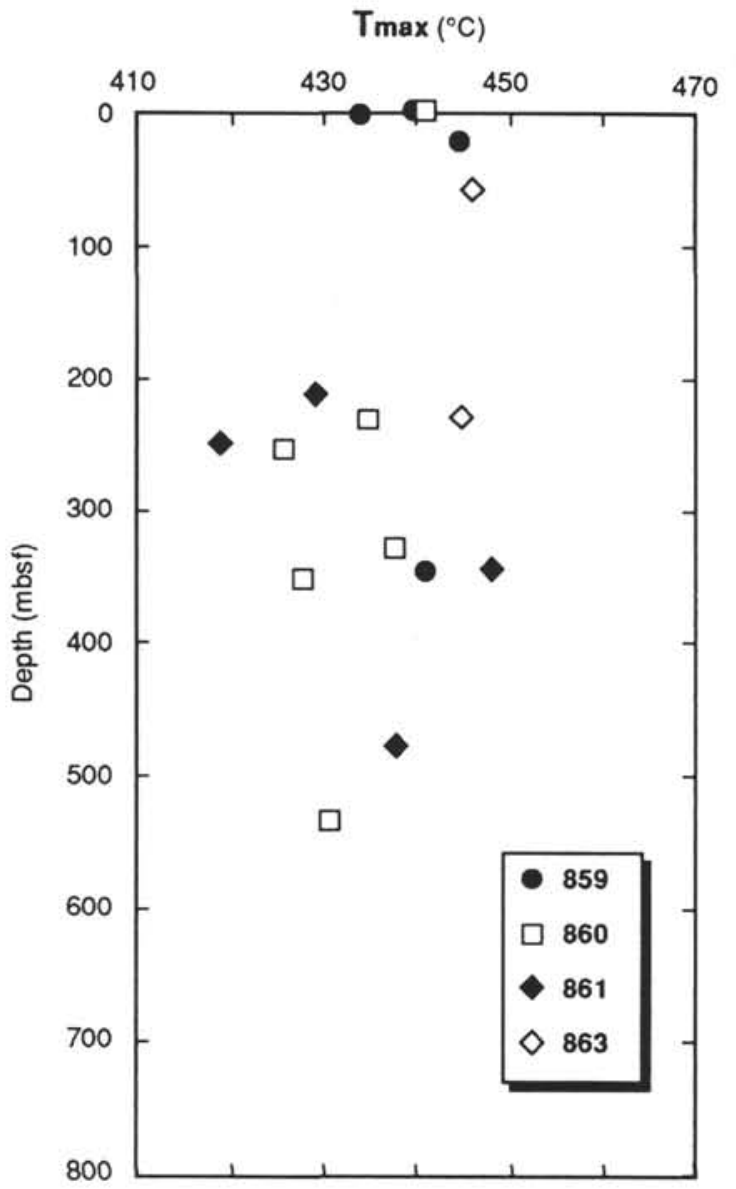

Figure 3. Rock-Eval $\mathrm{T}_{\max }$ profile of sediment samples from Sites 859,860 , 861 , and 863 .

\section{SUMMARY}

The $\delta^{13} \mathrm{C}$ values of kerogen show large variation with no downhole trend, ranging between $-34.2 \%$ and $-22.6 \%$ with average values around $-25 \%$, whereas the organic carbon contents in sediments are consistently low except for enrichment in the surface layer at Sites 859,860 , and 861 . The $\delta^{13} \mathrm{C}$ values of kerogen indicate the relative contributions of terrigenous and marine inputs to sediments. The relationship between the carbon isotope compositions and $\mathrm{HI}$ values show slightly positive correlation, indicating mixing of marine organic matter with heavier $\delta^{13} \mathrm{C}$ values and higher $\mathrm{HI}$ and terrestrial organic matter with lighter $\delta^{13} \mathrm{C}$ values and lower $\mathrm{HI}$.

The comparison of the $\delta^{13} \mathrm{C}$ values of kerogen and sedimentological core description of samples revealed that samples taken from the section interpreted to be turbidites have lighter $\delta^{13} \mathrm{C}$ values and samples taken from the section interpreted to be pelagic fallouts have heavier $\delta^{13} \mathrm{C}$ values, indicating the fine-grained turbidite material is associated with terrestrial organic matter. The average carbon isotope values become lighter with increasing distance from land (from Site 861 through 859 ) among three sites drilled along an east-west transect, suggesting fine turbidites with terrestrial organic matter are transported further offshore in this trench-slope setting.

\section{ACKNOWLEDGMENTS}

We are grateful to Japan Petroleum Exploration Company Ltd. and Empresa Nacional del Petróleo for allowing us to participate on Leg 141 and publish this paper. The laboratory assistance of Yoriko Abe is greatly appreciated.

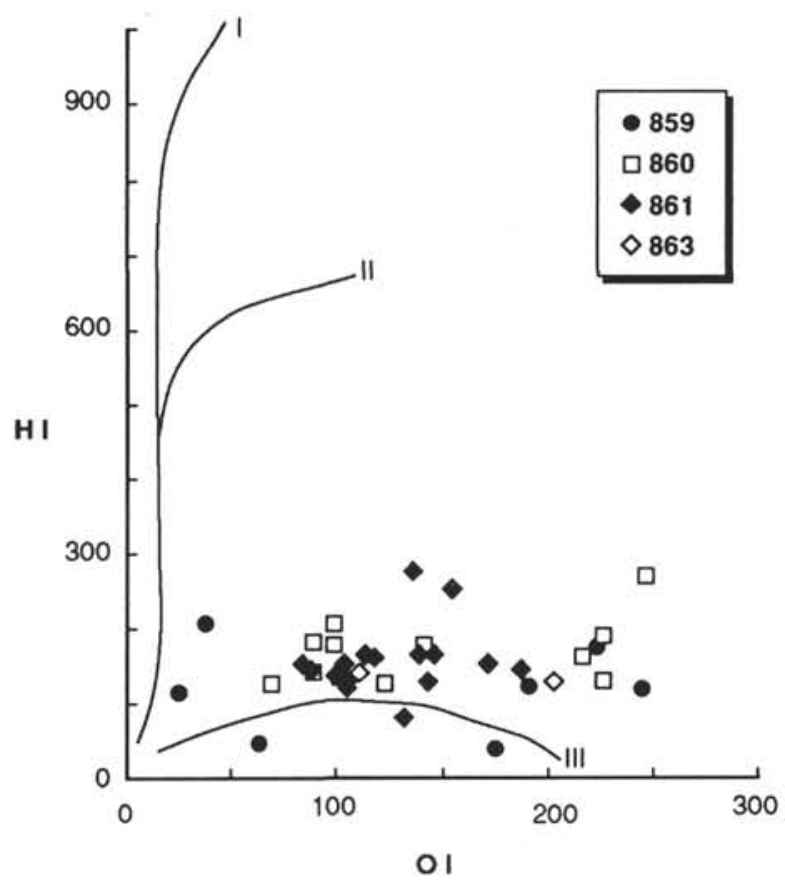

Figure 4. Hydrogen and oxygen indices of sediment samples from Sites 859, 860,861 , and 863 .

\section{REFERENCES}

Arthur, M.A., Dean, W.E., and Claypool, G.E., 1985. Anomalous ${ }^{13} \mathrm{C}$ enrichment in modern marine organic carbon. Nature, 315:216-218.

Behrmann, J.H., Lewis, S.D., Musgrave, R.J., et al., 1992. Proc. ODP, Init. Repts., 141: College Station, TX (Ocean Drilling Program).

Berner, U., and Koch, J., 1993. Organic matter in sediments of Site 808, Nankai Accretionary Prism, Japan. In Hill, L.A., Taira, A., Firth, J.V., et al., Proc. ODP. Sci. Results, 131: College Station, TX (Ocean Drilling Program), 379-385.

Dean, W.E., Arthur, M.A., and Claypool, G.E., 1986. Depletion of ${ }^{13} \mathrm{C}$ in Cretaceous marine organic matter: source, diagenetic, or environmental signal? Mar: Geol., 70:119-157.

Deines, P., 1980. The isotopic composition of reduced organic carbon. In Fritz, P., and Fontes, J.C. (Eds.), Handbook of Environmental Isotope Geochemistry (Vol. 1): The Terrestrial Environment, A: Amsterdam (Elsevier), 329-406.

Espitalié, J., Madec, M., Tissot, B., Mennig, J.J., and Leplat, P., 1977. Source rock characterization method for petroleum exploration. Proc. 9th Annu. Offshore Technol. Conf., 3:439-448.

Galimov, E.M., 1980. $C^{13} / \mathrm{C}^{12}$ in kerogen. In Durand, B. (Ed.), Kerogen: Paris (Technip), 271-299.

Gearing, P., Plucker, F.E., and Parker, P.L., 1977. Organic carbon stable isotope ratios of continental margin sediments. Mar: Chem., 5:251-266.

Hedges, J.I., and Parker, P.L., 1976. Land derived organic matter in surface sediments from the Gulf of Mexico. Geochim. Cosmochim. Acta, 40:10191029.

Macko, S.A., 1989. Stable isotope organic geochemistry of sediments from the Labrador Sea (Sites 646 and 647) and Baffin Bay (Site 645), ODP Leg 105. In Srivastava, S.P., Arthur, M.A., Clement, B., et al., Proc. ODP, Sci. Results, 105: College Station, TX, 209-231.

McIver, R.D., 1975. Hydrocarbon occurrences from JOIDES Deep Sea Drilling Project. Proc. Ninth Petrol. Congr., 269-280.

Muzuka, A.N.N., Macko, S.A., and Pedersen, T.F., 1991. Stable carbon and nitrogen isotope compositions of organic matter from Sites 724 and 725 , Oman Margin. In Prell, W.L., Niitsuma, N., et al., Proc. ODP, Sci. Results, 117: College Station, TX (Ocean Drilling Program), 571-586.

\footnotetext{
Abbreviations for names of organizations and publications in ODP reference lists follow the style given in Chemical Abstracts Service Source Index (published by American Chemical Society).
} 
Newman, J.W., Parker, P.L., and Behrens, E.W., 1973. Organic carbon isotope ratios in Quaternary cores from the Gulf of Mexico. Geochim. Cosmochim. Acta, 37:225-238.

Parker, P.L., Behrens, E.W., Calder, J.A., and Shultz, D., 1972. Stable carbon isotope ratio variations in the organic carbon from Gulf of Mexico sediments. Contrib. Mar. Sci., 16:139-147.

Peters, K.E., 1986. Guidelines for evaluating petroleum source rock using programmed pyrolysis. AAPG Bull., 70:318-329.

Sackett, W.M., 1989. Stable carbon isotope studies on organic matter in the marine environment. In Fritz, P., and Fontes, J.C. (Eds.), Handbook of Environmental Isotope Geochemistry (Vol. 3): The Marine Environment, A: Amsterdam (Elsevier), 139-169.

Schoell, M., 1984. Wasserstoff- und Kohlenstoffisotope in organischen Substanzen, Erdölen und Erdgasen. Geol. Jahrb., Reihe D, 67.

Shipboard Scientific Party, 1992. Site 861. In Behrmann, J.H., Lewis, S.D. Musgrave, R.J., et al., Proc. ODP, Init. Repts., 141: College Station, TX (Ocean Drilling Program), 239-299.
Stein, R., ten Haven, H.L., Littke, R., Rullkötter, J., and Welte, D.H., 1989. Accumulation of marine and terrigenous organic carbon at upwelling Site 658 and nonupwelling Sites 657 and 659: implications for the reconstruction of paleoenvironments in the eastern subtropical Atlantic through late Cenozoic times. In Ruddiman, W., Sarnthein, M., et al., Proc. ODP, Sci. Results, 108: College Station, TX (Ocean Drilling Program), 361-385.

ten Haven, H.L., Littke, R., Rullkötter, J., Stein, R., and Welte, D.H., 1990. Accumulation rates and composition of organic matter in late Cenozoic sediments underlying the active upwelling area off Peru. In Suess, E., von Huene, R., et al., Proc. ODP, Sci. Results, 112: College Station, TX (Ocean Drilling Program), 591-606.

Date of initial receipt: 15 July 1993

Date of acceptance: 5 November 1993

Ms 141SR-023

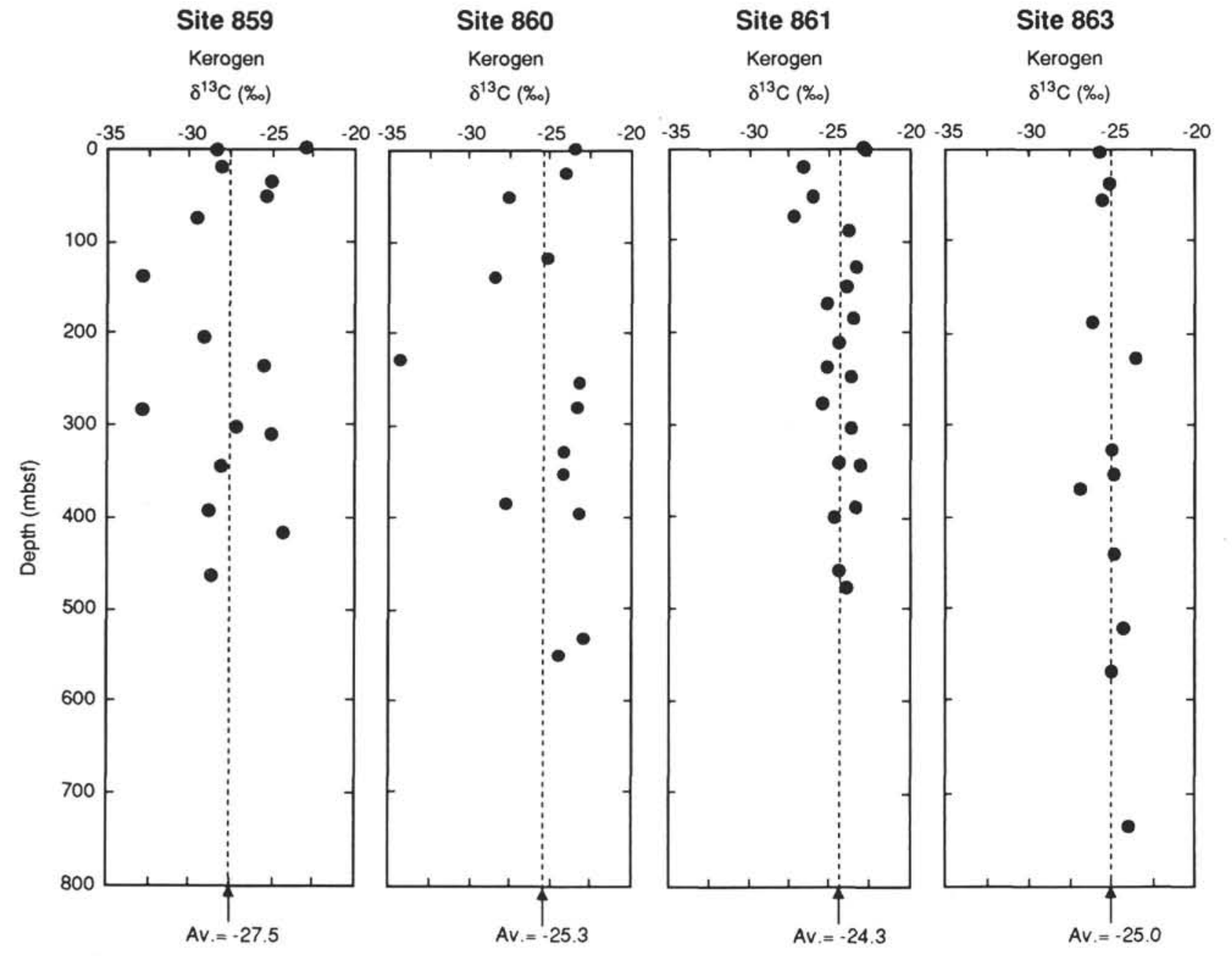

Figure 5. Carbon isotope profile of sediment samples at Sites 859, 860, 861, and 863. 


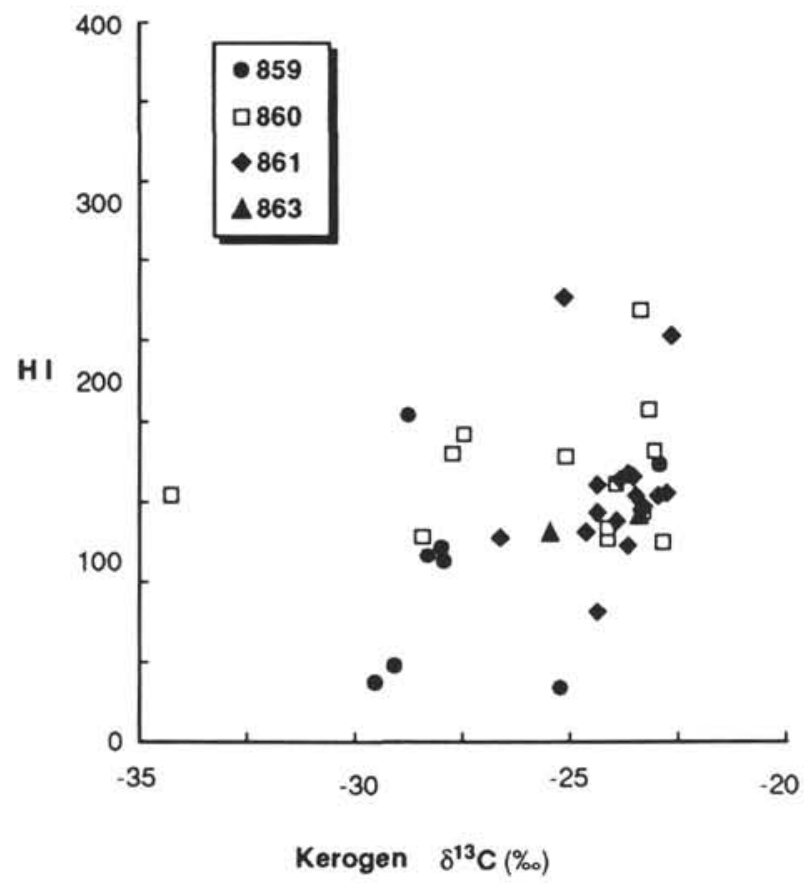

Figure 6. Hydrogen indices and carbon isotope compositions of sediment samples from Sites $859,860,861$, and 863 .

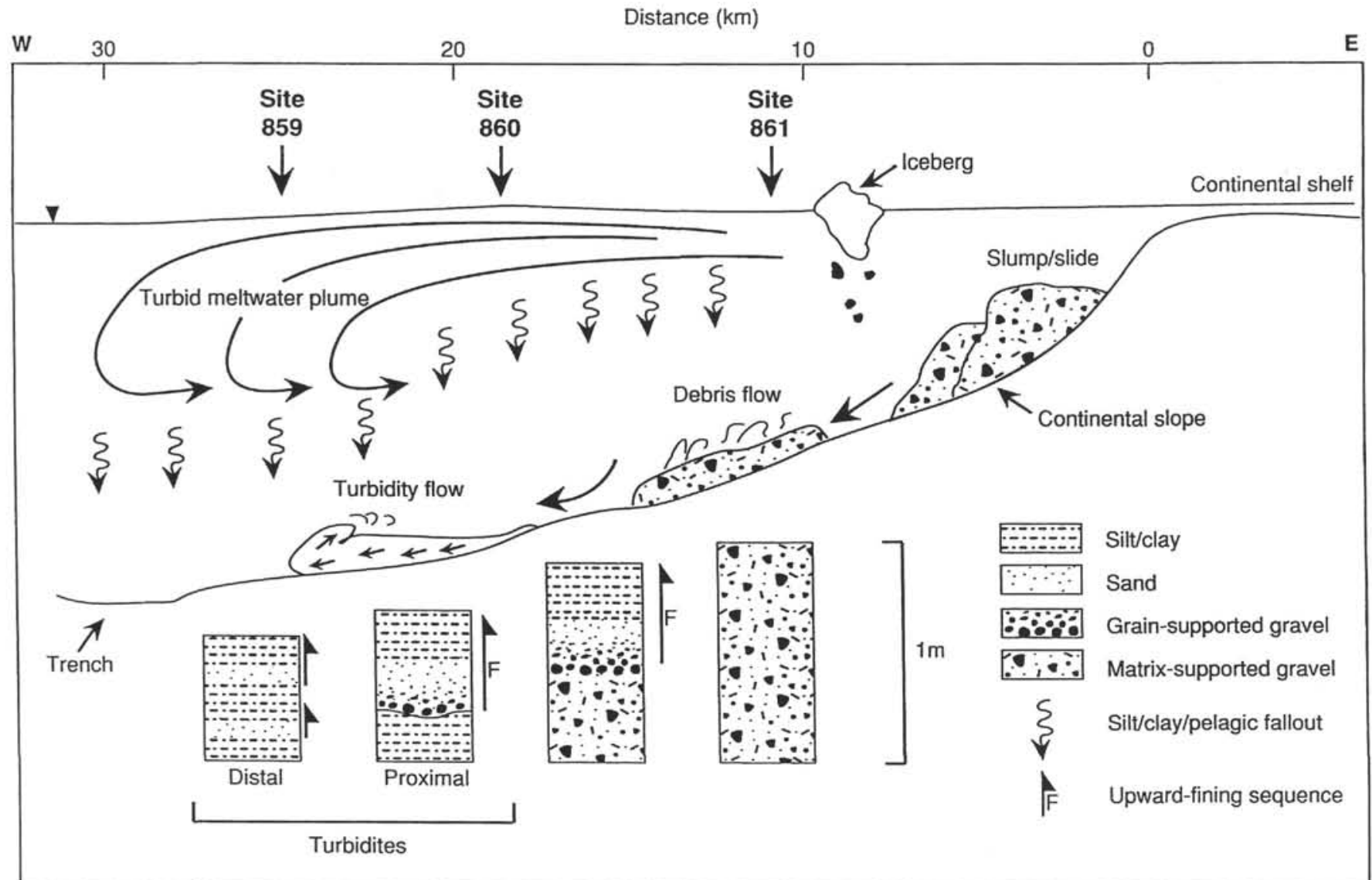

Figure 7. Possible depositional model for sediments recovered at Site 859, 860, and 861 (after Shipboard Scientific Party, 1992). 